\title{
The University-College Idea: A Critical Analysis
}

\section{JOHN D. DENNISON*}

\begin{abstract}
Following the recommendations of a committee on access to postsecondary education in British Columbia, a new institution, the university-college, was established in three locations in the province. This study is an analysis of the university-college idea.

The results indicate that, while the university-college has produced many beneficial results, it has also created a number of difficult issues. These issues include the survival of the comprehensive college curriculum, governance, expectations of faculty performance and the missions of the university-college itself. Each issue is discussed in this paper.
\end{abstract}

\section{Résumé}

La recommandation d'un comité sur l'accès à l'éducation postsecondaire en Colombie-Britannique, le "university-college", vient d'être mise en application par le gouvernement provincial dans trois institutions. Il s'agit ici d'une analyse du concept de "university-college".

L'analyse montre que cette nouvelle institution, bien qu' elle ait produit certains résultats utiles, soulève cependant quelques difficultés-le maintien du curriculum, les structures administratives, les critères d'admission et la mission de l'institution elle-même. Chacune de ces questions est traitée dans cette communication.

\section{Introduction}

In the past year a new concept in postsecondary education has evolved in the province of British Columbia. Generally termed the "university-college", this model evokes some quite unique perceptions of a traditional baccalaureate degree program in Canada, of expectations of faculty performance, of the traditional role of the community college, and of the relationships between conventional universities and somewhat less conventional colleges. In the light

* University of British Columbia 
of the interest expressed in the "experiment" and its implications for a different understanding of the traditional concept of a "university " in Canada, it is useful to examine this idea in some detail.

The purpose of this paper is to describe the context in which the universitycollege was conceived, its structure and function, and to assess critically both the accomplishments of the new model and the problems, real, potential, and perceived, which have arisen. The intent is not only to document this concept for the interest of other observers, but to furnish a "report card" which may guide future policy in this area.

\section{The Access Report}

In September 1988, the Provincial Access Committee submitted a report to the Minister of Advanced Education which examined in detail measures by which British Columbia's postsecondary educational institutions might address current limitations upon accessibility. The report presented evidence which revealed that the province ranked ninth in Canada with respect to degrees awarded (3.07/1000 of the adult population, as compared with Ontario's 6.05/1000), and seventh in full-time enrolment as a percentage of the $18-24$ age group (18\% as compared to Quebec's 34\% and Ontario's 25\%).

In particular, accessibility was seen as most limited for those living in rural and remote regions, and for various disadvantaged groups, including Native Indians. The various references to the wider issue were particularly disturbing when viewed in the context of a massive expansion of a variety of institutions of higher education during the past twenty-five years. Quite apart from an array of three universities and nineteen colleges, the province also has developed an Open College and Open University, with almost unlimited capacity for the delivery of instruction under distance learning formats.

Nevertheless, in the light of data which indicated that an additional 15,000 places in degree programs were needed if the province were to meet comparable national standards, the report made numerous recommendations about ways to address the problem. Examples of the latter included: greater expansion of open learning opportunities; the creation of a "quasi-independent" provincial council to initiate the resolution of difficulties associated with course and program equivalency and credit transfer; a review of financial assistance programs for students; authority for colleges to grant associate degrees; and the improvement of facilities for students by the provision of additional residences and greater extra-curricular opportunities. 
However, the specific recommendation which gave rise to the issue discussed in this paper was stated as follows:

It is recommended that in more densely populated college regions outside the Lower Mainland and south Vancouver Island (for example, Okanagan and Cariboo College regions), university degree programs be expanded by means of the establishment of an upper level university-college component (Report, 1988).

Judged on traditional Canadian practice, the concept of a "universitycollege," as envisaged above, is quite unusual. While some interesting structures do exist, such as the University-College of Cape Breton, the model proposed for British Columbia defies direct comparison.

\section{The Comprehensive Community College}

From their inception in the middle sixties, British Columbia's colleges have adopted a comprehensive curricular structure in which students may pursue a variety of program options. While full credit for the first two years of most university degree programs can be earned, students may also complete diplomas, certificates and other credentials in areas such as technical, vocational, high school equivalency, academic upgrading, and English as a second language, in addition to an array of credit-free courses.

The most unusual factor is that academic and vocational program options are integrated into an institutional arrangement which attempts to preserve equality of status, and maximum flexibility with respect to curricular organization. To this stage of their development, British Columbia's colleges have resisted elevation to degree-granting status for reasons similar to their counterparts in the United States. 1

It must be acknowledged, however, that, whatever the inherent qualities of the comprehensive college and the many opportunities afforded to students to begin academic programs, degree attainment in significant numbers has not been a hallmark of the B.C. system. Whether this deficiency is a reflection of institutional structures, geographic access, cost, or other many and complex reasons, is not fully evident at this time.

\section{The University-College}

Several major government initiatives followed the release of the Access Report. A Provincial Council on Admissions and Transfer, a quasi-independent body, 
was created and immediately became involved in setting policies and procedures which facilitate the transfer of credit among the province's postsecondary institutions. ${ }^{2}$ A provincial committee designed to address problems of literacy also was established. Legislation to create a Northern University in Prince George has been passed and a president appointed. But perhaps the most significant initiative was the one with which this paper is concerned, the creation of three "university-colleges."

The initial step in this respect, taken by the Ministry of Advanced Education and Job Training, was to issue a policy statement which contained, inter alia, the following:

(The university-college)...would be an organizational entity within each college, providing arrangements for upper level university courses, involving one or more of the three public universities and the Open Learning Agency.... Degrees would be granted by the university responsible for most of the instruction, or by the Open Learning Agency.

...A "university-college" component of a regional college, once established, could continue and expand as a "universitycollege"; or it could develop into an autonomous university; or it could lead to a comprehensive degree-granting regional college (Background Paper, 1988).

In addition to the policy statement, specific funding was announced to support the planning and operation of these new initiatives.

Three colleges were designated as sites for the new "university-colleges" and negotiations began between each of these institutions and each of the three public universities with regard to program selection and course design procedures, the hiring of faculty, arrangements for the transfer of credit, admission of students, etc:

The level of enthusiasm displayed by the three universities for the new initiatives varied. Nevertheless, after some hesitation and expressions of concern about financial arrangements, all three entered into negotiations with one or more of the three selected colleges. In each case, the understanding was that any arrangements would exist for five to ten years, after which time the colleges would assume responsibility for their own degrees.

Again, a variety of agreements emerged. One college elected to negotiate with one university and designated four degree programs, Arts and Science, Nursing, Education, and Social Work. The other two colleges chose to develop similar degree programs, with the addition of Business and Fine Arts, but entered into agreements with two universities in one case, and three in the other. 
It should be noted, parenthetically, that there was no serious consideration by any college of planning degree programs in conjunction with the Open Learning Agency. In practical terms such an arrangement would have been the least complex, as the OLA could have offered extreme flexibility with respect to course delivery, and also would have allowed college students to take advantage of the credit bank, and to have access to a range of courses from all universities which could collectively constitute a degree.

However, OLA is facing an obstacle characteristic of all institutions which are new and unconventional - credibility in the public mind! Quite independent of quality questions is a problem of perception, and rural residents of the province, in particular, seek assurance by cooperating with established institutions which employ conventional face-to-face instruction in regular classroom settings.

By September 1989, the three "university-colleges" in the province had hired several new instructors, enrolled a reasonable number of students, ${ }^{3}$ and commenced operation. The first graduating classes crossed the stage in June of 1991 .

It is now possible to assess the initial results of the "university-colleges" idea and, in doing so, to unearth a number of issues, both anticipated and otherwise, which have arisen.

\section{The Access Issue}

It is already evident that the goal of greater access to degree programs has been accomplished. As one instructor noted, "many excellent students have not continued their education in the past because of insurmountable obstacles which prevented their moving to the coast." Several of these students are now apparently continuing to study for a degree in the college.

It must also be recognized, however, that the colleges are able to offer only a limited range of degree programs, and within these, an equally limited number of majors. Students seeking most professional degrees and specializations still face the task of relocation to Victoria or Vancouver. The extent to which the university-colleges can extend their program offerings, if and when they gain degree-granting independence from the established universities, is a matter of conjecture.

A second factor in the access issue has been the somewhat dramatic increase in enrolments in the second year of the colleges' academic programs. For many years the colleges have been frustrated in their efforts to retain students after first year. Those who are able to pursue degrees have tended to transfer to a 
"coastal" university after just one year of study, largely because of the limited course offerings in the college. Evidently, the option of pursuing a degree in their local college has convinced many students to continue into second year. In turn, faced with an acceptable critical mass of students, the colleges have been able to expand their course offerings.

\section{The Academic Climate in the Colleges}

Another positive result of the move to university-colleges which is already apparent is the effect upon the "academic climate" of the colleges. Since their initial appointment, college instructors in both academic and non-academic program areas have been committed to teaching, largely to the exclusion of other scholarly activity. With few exceptions, there has been little attention to research, writing, or conference presentations. The heavy teaching loads and often large class sizes, and the lack of course markers, graduate student assistance, or other support, have always been regarded as obstacles. Furthermore, few incentives to pursue other scholarly activity have existed, as those rewards which do occur have rested upon quality of teaching and student contact.

In addition to the above, many years of teaching introductory courses over and over again have contributed to intellectual fatigue and diminishing morale among instructional staff. Recent demand for greater productivity as a condition for additional funding has also taken its toll.

The development of the university-college, with an accompanying increase in the number of second year academic students, the arrival of new instructors and the well-publicized expectations of the universities with respect to faculty qualifications and performance, have all contributed to a new "academic climate" in the colleges. Instructors have displayed interest, often long dormant, in various areas of scholarship. Many seek to improve their qualifications, others are writing papers and seeking opportunities to present at scholarly conferences. Furthermore, the increased number of students at the second year level has provided opportunities to teach new courses, pursue academic specialties, and confront a range of instructional challenges.

While, as will be noted later, heavy workloads remain a problem for scholarly activity, instructors of long tenure have found an intellectual incentive through contact with new colleagues and the challenge of different course preparations. This enthusiasm also appears to have permeated the technical and vocational staff, as the latter recognize opportunities to strengthen their contributions to the evolving university-college. 
The overall task of creating a university-college, integrating it into an established institution, and negotiating with a university on matters of curriculum and general academic issues has become a focus of discussion and debate which, whatever the outcome, has proved to be both stimulating and controversial for college personnel.

\section{Problems Relating to Instructional Staff}

The entire issue of the hiring of new instructors, of their status and their joint relationship to the college and the university, in addition to the conditions of their employment, have become matters of both complexity and sensitivity.

While, as noted earlier, faculty chosen to teach in the third and fourth years were jointly selected by the appropriate college and university departments (although the latter effectively retained "veto" power), they were employed by the colleges and hence became members of the respective unionized instructor organizations. The latter circumstance was greatly influenced by positions taken by the individual faculty associations and by the provincial organization, the College and Institute Educators Association (CIEA). The intent behind these positions was that faculty not be fragmented into two distinct groups, with accompanying implications for status and working conditions. Two separate faculty units, those who teach degree students, and those who do not, would, in the view of CIEA, constitute a "university component" antithetical to the goals of an integrated institution.

In a position paper on this issue, one instructor organization makes the following statement...

The Faculty Association has expressed its commitment to keeping its membership unified and integrated-i.e. without undue hierarchical stratification-and that would suggest that research opportunities be extended to instructors teaching first and second year courses (Response, 1990).

As expected, the universities, sought faculty with advanced academic credentials, a Ph.D. where appropriate. Equally expectedly, the colleges tended to give first preference for new degree teaching positions to their established faculty, where qualified. In general, this arrangement was reasonably successful, but a number of additional instructors had to be hired. In these cases, the position of the college faculty organizations was that the new appointees would be expected to teach both lower division and upper division courses, a practice consistent with that in universities.

One significant outcome of this process was that colleges now employed a number of individuals, who, while well-qualified academically, had little 
experience or real appreciation of the comprehensive community college and its carefully nurtured values. Furthermore, the new appointees were understandably sensitive to the expectations of the "parent" university departments for scholarly activity, in addition to teaching performance, as a measure of quality. Scholarly activity, however, demands both time and resources; and, again understandably, the new faculty soon recognized the difficulties encountered when required to teach 14-16 hours a week, in accordance with the collective agreement. The solution, albeit tentative and/or short-term, was for the faculty associations to agree to come compensatory lightening of teaching loads as an exclusion within the agreement. ${ }^{4}$

A definition of "scholarly activity" also became a topic of negotiation between college and university representatives. One college prepared a policy statement which included the following...

Scholarly activity shall be understood to include continuing mastery of one's field of knowledge, awareness of current scholarship in one's own field, involvement in basic research and development, and professional or creative activity (Policy, Okanagan College, 1990).

The question of the title which academic instructors in degree programs would hold became a controversial and divisive issue. Those coming from a university milieu were reluctant to assume the title of "instructor", particularly if they had previously held assistant professor rank. The approach to this issue varied among the three colleges. To mixed reaction, one college settled upon "college professor." Another proposed a university-like system of ranks based upon meritorious performance. The third college seemed reluctant to address the issue.

There are many other issues of a similar nature which inevitably will have to be confronted as the university-college concept unfolds. For example, university practices so far absent in colleges, such as academic rank and promotion policies, merit pay, sabbatical leave, 'and the idea of tenure in relation to academic freedom, have yet to be debated, let alone resolved.

It is interesting to note that at least two instructors from the comprehensive college milieu have reflected upon the university-college values debate and its effects upon the climate in the college. Ian Johnson (1990) expressed concern that the universities' emphasis on research and publication has serious implications for the integrity of the teaching role of the college. Bill Christensen (1989) asked whether degree-granting status is compatible with the community college mandate. 


\section{The Mission of the University-College}

While the issues raised in the previous section are of varying significance, there is a more intriguing implication, that of the definition and role of a degreegranting institution outside the realm of a conventional university.

By tradition, a "university" in the Canadian context pursues three activities: teaching, research, and service. Unlike the situation in the United States where many four year colleges (or in some states, universities) offer degrees, usually in Arts and Sciences, and regard themselves as essentially "teaching" institutions, no Canadian province has adopted such a model. 5 Professional degrees, graduate programs and an emphasis upon research are all, to a greater or lesser extent, characteristic of Canadian public degree-granting institutions (Skolnik, 1990).

By contrast, each of B.C.'s university-colleges has expressed the intention of evolving towards independent degree-granting status, while at the same time preserving the comprehensive community college as an integral part of its structure. The emphasis in the degree programs will be quality teaching, consistent with the primary purpose of the college idea.

For example, a mission statement issued by one college places "comprehensiveness" as its first value, noting...

Cariboo College values its comprehensive approach to the provision of educational programs and services in its vocational, career/technical, college preparatory and university program areas. The College believes that through a balanced profile of programs-many of special provincial significance-it can best meet the needs of the region it serves. The institution is committed to the concept of lifelong learning and sees the provision of a laddered curriculum with numerous entry and exit points for students as the best way to promote this (Mission Statement, 1990).

And, from a policy statement prepared by the president of another college involved in this exercise, the following statements are of significance...

Generally, the college community is concerned that the nature of the College remain as comprehensive as possible with a focus on excellent teaching and service to the students. The College is concerned that we stay under the Colleges' Act or some form of the Act so we do not have to deal with the cumbersome format of the Universities' Act....The College is 
also concerned that the focus remain on teaching and not research, although we recognise that a certain amount of research, especially applied research, is desirable (Johnston, 1990).

There are several questions which arise from this plan. Can the comprehensive college concept survive? Is it possible for an institution to develop degree programs and, at the same time, continue to offer adult upgrading, English language instruction, apprenticeship programs, and a variety of vocational, technical and short term pre-employment training? Polytechniclike institutions in the United Kingdom and Australia, and Ryerson Polytechnical Institute in Canada, have all yielded to pressures to eliminate or reduce non-degree programs. Are degree programs compatible in the same institution with non-degree programs? The pressures upon teaching faculty to adopt a status associated with a "university" in Canadian terms will surely be intense. No less pressure is likely to generate from community groups who recognize the value of a "university" as an important stimulus to regional economic growth and diversification.

The comprehensive college has served British Columbians extremely well. Academic programs are an important ingredient of its make-up. However, the real challenge of the future for university-colleges will be to resist dissolution into two clearly separate institutions - a university and a college- in a community with a limited population, as is the case, for example, in Lethbridge, Brandon, Thunder Bay, and Sudbury. The preservation of the university-college concept will demand leadership, imagination and faith!

It is of significance to note that one university-college, having sought and gained the authority to expand its capital resources, primarily as a result of a lack of suitable land, has been compelled to build a new campus some miles distant from its present major location. The new campus is to house its academic degree programs and courses only. Not surprisingly, there are many in the present college who anticipate that the new campus will eventually become the site of a separate university. While the management group in this college is committed to preserving the comprehensive institution, many observers, both internal and external, remain unconvinced.

\section{Governance}

Another issue which will inevitably rise in the university-college environment is governance. Under the present legislation, all governing authority, subject to Ministerial approval, rests with the college board. Unlike the policy in 
universities, faculty have no prescribed role in decision making - academic or otherwise. Nor do representatives of faculty (or support staff, or students) serve on the boards. 6

It has been noted that new appointees to instruct in degree programs tend to come from an environment quite different from colleges. They expect, even assume, that they will be formally involved in academic policy making, particularly in areas relating to curriculum, admission policies and evaluation. This view has been shared for some time by many faculty in the colleges' academic programs. The latter enthusiastically endorse any initiative towards more participatory governance.

As discussed earlier, instructors in the degree program at the third and fourth year levels have been accorded reduced teaching loads in order to meet the universities' expectations of scholarly activity. It comes as no surprise that some regular college instructors in the first and second year levels also see themselves as "degree program" faculty and would like similar opportunities to engage in scholarship. Some perceive the creation of a "senate-like" body, with wide faculty representation and statutory powers, as a logical forum to argue their case.

One other example of a governance issue which has arisen is the final authority over course selection in the senior years of the degree programs. The practice in colleges has been that administration has retained formal control. However, some faculty are becoming increasingly concerned about course selection and believe that such decisions should properly rest in the department. In the absence of any formal role for faculty in curriculum matters, the problem will not be ameliorated.

At the present time there is little indication that amendments to the governance section of the College Act are imminent. Presumably, faculty will continue in an advisory capacity for the foreseeable future. However, if as currently anticipated, colleges gain independent status as degree granting institutions, reform of the governance structure will be inevitable. Meanwhile, academic faculty will continue to urge government for legislative action in this area.

\section{Relations with the Universities}

While in the initial period, as least, the degrees which are available in the colleges are under the aegis of the various universities, the latter are playing a major role in the entire exercise. As noted earlier, faculty teaching in the degree programs are under considerable pressure to meet the respective sponsoring 
university's expectations for scholarly activity. In matters concerned with course design and curricula, even course numbering, it is the universities which are setting the rules. Needless to say there are some in the colleges who view the situation as unduly paternalistic, and not necessarily inevitable. Again, a faculty association brief notes...

It was suggested that forwarding course outlines, reading lists and grading procedures "before each occasion...for approval" was both unnecessarily burdensome and time consuming. Is this required for instructors at U.Vic.? Could not the intent of this proposal be carried out more effectively by consultation between departments as necessary? (Response, 1990, p. 3)

Another observer also notes that academic regulations differ between colleges and universities in many respects, including course challenges and appeals, grading systems, course weighting, and English language proficiency requirements (Johnston, 1990).

Although many students prefer to specialize in B.A. and B.Sc. programs, academic resources available in the colleges have limited the number of majors, and some general degrees have been developed. One of the sponsoring universities has been embroiled in a debate about a general degree in Arts for some time. The availability of the degree in the college proved to be a stimulus to resolving the issue in the university.

One college proposed a general liberal studies degree with a strong interdisciplinary focus. While the "parent" university has no equivalent degree program, it has received the proposal favourably, despite reluctance on the part of some departments.

The "ownership" of the students in the degree programs has also been a subject of debate. As noted earlier, the universities have retained authority in the admission of students to the degree programs, their promotion and retention, and over the design of the curriculum and the numbering of courses. On the other hand, the colleges have insisted that their programs are not merely "satellites" of the universities, where the latter merely run their courses on the college campus. The students are "college" students, a designation which, although eliminating them from qualifying for university loans and scholarships, does ensure that the final degree is awarded by the university "in association" with the respective college.

In spite of the difficulties noted above, however, the cooperation of the universities has been notably generous. Help, advice and guidance have been given freely by university representatives who, while seeking to ensure quality, 
are also generally sensitive to the problems faced by the colleges in undertaking this enterprise. These initial negotiations will be invaluable in the future when colleges not only offer standard degrees in Arts and Sciences, but hope to develop new and specialized degrees in areas such as respiratory therapy, medical laboratory technology, and health sciences administration.

One final matter of overriding concern is the question of library facilities. Well-equipped libraries remain an essential ingredient for the cultivation of scholarly activity, for quality of instruction, and for the academic content of the college programs. While the universities have attempted to supplement college libraries, inter-library loan is both expensive and difficult to administer. The expansion of university-college libraries remains a priority with considerable budgetary implications.

\section{Conclusion}

The university-college idea, as described in this paper, represents a new model of postsecondary education in Canada. Such experiments are relatively rare. All provincial universities follow a conventional pattern. They all value, in varying degrees, the three primary functions - research, teaching and service. Almost all seek greater recognition by adding graduate and professional programs. Virtually all place high importance upon research activity and the grant money which accompanies it.

Provincial community college systems, conceived and developed during the 1960 s and 1970s, display extraordinary diversity from province to province. In general terms, colleges reflect the historical, socio-cultural, geographic, economic, and educational differences which characterize the regions of Canada. Each system attempts to merge government priorities with the needs of its clientele. Although few in number, other types of institutions may be found in various provinces. Technical institutes, schools of art and design, agricultural and vocational colleges, forestry, marine training and nursing schools, all pursue a limited mandate for an equally limited segment of the population.

The university-college, however, is a new concept. With the notable, but not identical exception of the University-College of Cape Breton, British Columbia's three such colleges are unique in structure, purpose and function. They attempt to incorporate two fundamentally different cultures, the comprehensive community college and the conventional university, and strive to preserve a climate in which values such as "parity of esteem", status equity, and internal cohesion prevail. (Table 1) 
Table 1

$\underline{\text { University vs. College Values }}$

\section{UNIVERSITY}

\section{ACCESSIBILITY:}

Selective admissions based upon previous academic performance; Application of quota policy

\section{CURRICULUM:}

All programs designed upon academic content and theoretical bases.

\section{FACULTY PERFORMANCE:}

Research, teaching and service, with strong emphasis upon contribution to knowledge.

\section{RESPONSIVENESS \&} FLEXIBILITY:

Primarily influenced by developments in research areas and demand for highly skilled graduates in selected programs.

\section{GOVERNANCE:}

Bicameral governance, i.e. senate and board. Faculty have substantive input into academic policy,

\section{COLLEGE}

\section{ACCESSIBILITY:}

"Open door" admissions

policy (where viable).

Increased access to disadvan-

taged groups.

\section{CURRICULUM:}

Comprehensive mix, including some or all of academic, vocational, technical, adult upgrading programs.

\section{FACULTY PERFORMANCE:}

Primary emphasis upon teaching and student services.

\section{RESPONSIVENESS \& FLEXIBILITY: \\ Continuing response to changing needs in community clientele, employer groups, and government priorities.}

\section{GOVERNANCE:}

All authority resides in board. Faculty have advisory power, at best.

Inevitably, the universities will sever their supervisory and somewhat paternalistic association with the colleges and the latter will take responsibility for their own degrees. If their current plans to develop a four-year college concept, rather than a "university," are realized, the colleges will have created a 
degree-granting structure generally unknown in Canada. The task will then be to attract faculty who value teaching, rather than research, and are content to be a part of an institution seeking status in its own right by establishing its own values.

In this context, it is interesting to consider the remarks of William Saywell, President of Simon Fraser University, in addressing the AUCC Commission of Inquiry on Canadian University Education...

There is no mature, good Canadian university that exists now that is not research intensive. There is no good academic community...that wishes to be strictly an undergraduate teaching institution. The sooner we get this debate behind us, the better (Saywell, 1990).

The survival of the comprehensive community college is also problematic. Non-degree programs in technical, vocational and adult basic education will face pressure from both faculty and community groups wedded to the aura of the conventional university. If bifurcation into two institutions, with all its attendant status and related problems, is to be prevented, sensitive and imaginative leadership will be essential. In this writer's view, the solution lies in ensuring that the degree "stream" is simply seen as another program available in the university-college, as are technical diplomas, vocational certificates and perhaps associate degrees. If a demand for the traditional trappings of the conventional university, such as professorial titles, a primary focus upon research and grant-getting, and pressures upon faculty to publish, can be controlled, the university-college may well survive.

With a limited but diverse population, the comprehensive university-college can offer a sufficient range of programs in an atmosphere which values and rewards good teaching, while still allowing for maximum flexibility for a clientele composed of many age groups. As Astin (1985) notes, excellence may be better achieved through the development of talent in students, in cognitive and affective terms, rather than from traditional measures which are generally rooted in the reputation of the institution. The university-college has the potential to fulfil every criterion of excellence with respect to the "value added" concept of the role of postsecondary education. A major step towards the establishment of a new, vibrant and creative postsecondary educational institution in Canada has been taken in British Columbia. It yet must face the challenge of survival.

\section{Notes}

1 Community colleges in the United States have traditionally resisted degree-granting status, regarding such policy as antithetical to a comprehensive structure. 
2 The Council has already produced a single fully comprehensive "transfer guide," in which all institutions show courses with credit equivalency.

3 Numbers in degree programs may vary. They are generally high in Arts, but limited in Sciences.

4 Other incentives to stimulate scholarly activity, such as financial assistance in one college, have been provided.

5 It is interesting to note that Trent University has chosen to emphasize undergraduate instruction in smaller classes and seminars, and, as a consequence, has received additional funding to compensate for higher instructional and adminstrative costs per student (1989-1990, Annual Report, Ontario Council on University Affairs).

6 The College Act currently provides for a "program advisory committee," with faculty and student representation, but no terms of reference.

\section{References}

Astin, A.W. (1985). Achieving educational excellence. San Francisco: Jossey-Bass.

Cariboo College. (1990). Mission Statement. Cariboo College, Kamloops, B.C.

Christensen, W. (1989). Degree granting status - Extending or impoverishing the college mandate. Paper presented at the ACCC Convention, Regina, Saskatchewan.

Johnston, Ian. (1990). Teaching, research, and academic publishing. Unpublished paper, Malaspina College, Nanaimo, B.C.

Johnston, Richard. (1990). Important issues concerning the management of university/college and vocational programs. Unpublished paper, Malaspina College, Nanaimo, B.C.

Malaspina College Faculty Association. (1990). Response to: Proposed guidelines for teaching upper division arts and science courses at Malaspina College for credit towards U.Vic. degrees. Nanaimo, B.C.

Ministry of Advanced Education. (1988). Access to advanced education and job training in British Columbia. Report of the Provincial Access Committee. Victoria, B.C.

Ministry of Advanced Education and Job Training. (1988). Background paper: University college. Victoria, British Columbia.

Okanagan College. (1990). Policy for scholarly activity. Kelowna, B.C.

Saywell, William. (1990, Nov. 16). Remarks to commission of inquiry on university education. Reported in the Ubyssey, The University of British Columbia, November 16.

Skolnik, M.L. (1990). Lipset's continental divide and the ideological basis for differences in higher education between Canada and the United States. Canadian Journal of Higher Education, 20 (2), 81-94. 